\title{
AN EMPIRICAL SURVEY OF RESIDENTIAL WATER DEMAND MODELLING
}

\author{
Andrew C. Worthington \\ Department of Accounting, Finance and Economics, Griffith University \\ Mark Hoffman \\ School of Economics and Finance, Queensland University of Technology
}

\begin{abstract}
The increased reliance on demand-side management policies as an urban water consumption management tool has stimulated considerable debate among economists, water utility managers, regulators, consumer interest groups and policymakers. In turn, this has fostered an increasing volume of literature aimed at providing best-practice estimates of price and income elasticities, quantifying the impact of non-price water restrictions and gauging the impact of nondiscretionary environmental factors affecting residential water demand. This paper provides a synoptic survey of empirical residential water demand analyses conducted in the last twenty-five years. Both model specification and estimation and the outcomes of the analyses are discussed.
\end{abstract}

Keywords. Water demand; Demand side management; Price and income elasticity

\section{Introduction}

Water supply efficiency and demand management are increasingly important issues for residential water supply authorities throughout the world. Population growth, coupled with the reduction in freshwater supplies and the increasing cost of infrastructure, has prompted suppliers to place renewed emphasis on demand management through pricing structures and other strategies to control consumption. At the same time, the impact of global warming with potentially higher demands and lower supplies, and the higher values placed by the citizenry on environmental protection and sustainability have also had a role to play. Clearly, there is the need for better demand forecasting: given the real cost and value of water is now significantly higher, so too is the possible loss from under- or over-prediction of demand.

Concurrently, there is ongoing debate about the competing demands of consumers and other stakeholders. Klawitter (2003), for example, argues that sustainable urban water pricing must be designed to meet, amongst others, the needs of current and future generations, resource use efficiency, full cost recovery (including supply costs, opportunity costs and economic externalities), economic viability of the water utility, and equity and fairness for different users. Dalhuisen et al. (2001) agree that the pricing structure should cover costs, be fair, induce economically efficient usage (i.e. meet the long run marginal social cost), and be administratively feasible. One important outcome of this debate has been a reorientation of public policy in that agricultural, industrial and commercial water use is not the only focus of 
attention. With households accounting for a substantial proportion of total water supply use in most developed economies, residential water demand has become a principal concern of policymakers.

In response, an extensive body of literature around the world has concerned itself with the estimation of residential water demand functions. In a multiplicity of contexts, these studies have analyzed a range of market and non-market systems with different tariff structures with an assortment of samples. Nevertheless, they share a common focus; namely, providing bestpractice estimates of price and income elasticities for designing better charging regimes, quantifying the impact of non-price water restrictions to judge their effectiveness in controlling demand, and gauging the impact of environmental factors to identify the sources and magnitudes of discretionary and non-discretionary water usage. They also have a focus on average rather than peak demand, so the literature is necessarily concerned with using prices to manage overall demand, rather than the different peak demands that arise on an hourly, daily, weekly, monthly or other seasonal basis. The resultant elasticity estimates must, of course, be viewed from this perspective.

The findings from such research are not uncontentious. While economists generally agree that urban water prices that reflect marginal costs are a means of reducing demand during periods of limited water supply availability, others argue that urban water demand is relatively price inelastic, and therefore price is an ineffective tool for regulating demand and consumption. Supporters of this viewpoint suggest that more appropriate mechanisms for regulating water consumption are non-price strategies, encompassing public education campaigns, rationing, water use restrictions and the subsidisation of programs aimed at adopting more water efficient technologies. Proponents of the alternative argue that non-price controls, especially water restrictions, decrease consumer welfare, increase deadweight losses, are inequitable and unpopular and place an unnecessary administrative burden on struggling public and private sector water utilities.

\section{Scope and Contribution of Survey}

At least one study, Arbues et al. (2003), has surveyed the estimation of residential water demand. However, few papers included in that survey were published after the late 1990s, and there is an emphasis placed on the earliest modeling approaches. Other possibilities include the meta-analyses by Espey et al. (1997) and Dalhuisen et al (2003). While these suffer from the usual limitations of meta-analysis - they cannot improve the quality or reporting of the original work, diversity is often ignored or mishandled, and the variability of the sample, the quality of the data, and the potential for underlying biases are not addressed - 
they also necessarily focus on providing indicative measures of price and income elasticity, and are not particularly useful for researchers undertaking new work. Apart from discussing the strengths and weaknesses of the different empirical methods, this article examines the steps faced by researchers as they move from a selected approach, to model specification, to the interpretation of results. All of this information is summarized and tabulated on a studyby-study basis. This highlights the empirical problems that have received attention in the literature, and the efforts by researchers to overcome these problems. It therefore provides guidance to those conducting empirical research in residential water demand and is also an aid for policymakers, consumer interest and environmental groups, regulators, water utility managers and industry practitioners interpreting the outcomes of these studies.

This review concentrates on studies published since 1980. EconLit, the Journal of Economic Literature electronic database, was searched to identify articles concerned with residential water demand estimation. References from these studies were used to identify other articles not included in the database. Because of this selection process, most of the studies are journal articles, with relatively fewer discussion, conference and project papers. Of the thirty-seven studies presented in Table 1 (recent examples in brackets), fifty-six percent are based on samples in the United States (Renwick and Green 2000; Gaudin et al. 2001; Timmins 2002); twenty-four percent are in Europe (Nauges and Thomas 2000; Martinez-Espineira 2002; Nauges and Thomas 2003), sixteen percent are in Australia (Higgs and Worthington 2001; Hoffman et al. 2006) and the remainder are in other settings. Most employ least squares regression techniques in some way, with the remainder using other techniques, including logit, generalized methods of moments, instrumental variables and cointegration.

However, despite their dissimilar contexts and techniques these studies mostly share a common step-by-step empirical procedure that first determines the choice of estimation method, and second the specification of dependent and independent variables to be used in the selected approach. This usually takes the form: $\mathrm{Q}_{\mathrm{D}}=f(\mathrm{P}, \mathrm{Z})$ where $\mathrm{Q}_{\mathrm{D}}$ is the quantity of residential water demanded (more likely consumed), $\mathrm{P}$ is some measure of water price, and $\mathrm{Z}$ represents other independent variables thought to impact upon residential water demand. These usually include income, household structure and size, property characteristics, nonprice water restrictions and so on (Arbues et al. 2003).

This specification is entirely generalisable in that cross-sectional, time-series or pooled cross-sectional and time-series (panel) data can be employed. It can also include data from either a sample of individual households, the whole of the residential sector where consumption from the population of households is summed, and in some cases, whole-of- 
utility consumption which may include some influence (and possible bias) from the presence of non-residential water consumption (i.e. agricultural, commercial and industrial). The estimated parameters of this model are the key to identifying several important economic relationships likely to assist demand side management policies for urban water consumption. First, the provision of price and income elasticities of demand to evaluate the impact on quantity demanded to changes in price and income. Second, the impact of non-price factors on both discretionary and non-discretionary urban water consumption can be ascertained. Finally, the level of interaction between these factors of demand can also be revealed.

\section{Tariff Metering, Structure and Billing}

A key feature of demand side management policies is the pricing structure used to apply to water services. Study of the effects of pricing structure can explain how effective price has been in regulating water consumption and thereby how successful price has been in meeting the multiple objectives usually taken into account when designing an optimal pricing policy. For the most part, the empirical researcher is likely to find that a particular tariff structure is already in place, perhaps for some time. And since the observations used for deriving demand are drawn from this context, a good knowledge of the existing tariff structure is essential for the purposes of model specification. Invariably, pricing structures are complex, meeting or attempting to meet, the varying and often competing objectives of equity, financial stability, simplicity, public acceptability and transparency, efficiency, the sustainability of service provision and profitability. For the purposes of demand estimation, three salient features need to be established: (i) the presence of individual household metering; (ii) the structure of prices representing the split between fixed and variable prices and any variance in these prices; and (iii) billing frequency indicating how often bills are issued to paying households for their water consumption.

A variety of alternative charging methods has been employed in the past in an attempt to meet these criteria (Dinar and Subramanian, 1998; Bartoszczuk and Nakamori, 2004). These include a fixed charge invariant to the level of consumption; a fixed charge with a free allowance followed by some excess charge for consumption over a particular level; and, as is common in Australia and elsewhere, a two-part tariff consisting of a fixed component (an access charge) and a usage component based on the actual amount of water consumed (a volumetric charge). The latter can be non-linear if the cost per additional unit varies when consumption reaches certain thresholds. In this way, the tariff consists of a sequence of different marginal prices for different consumption blocks. These prices per kilolitre (or gallon) of water consumed can be constant (a fixed block), increasing with each successive 
block of water use (an increasing block), or decreasing with each successive block of water use (a decreasing block). By far the most complex block style tariff structure reported is by Arbues et al (2001), who sheds light on charging practice in Zaragoza, Spain. Under the local water supply mechanism, there are 140 progressive pricing blocks, with the total bill charged at the highest block price for the period.

Because of the overwhelming dominance of US studies of residential water demand, tariff structures including increasing and decreasing blocks have been well investigated. For example, Billings and Agthe (1980), Agthe et al. (1986), Agthe and Billings (1987), Renwick and Archibald (1998), Gaudin et al. (2001) have conducted analyses of increasing block structures, Chicoine et al. (1986) and Williams and Suh (1986) have examined decreasing blocks, while Foster and Beattie (1981), Schefter and David (1985), Nieswiadomy and Molina (1989) and Timmins (2002) have included both increasing and decreasing block regimes. But outside of the US there is generally less variation in side-by-side tariff structures. For example, increasing block rates dominate studies in Spain [see MartinezEspineira (2003a; 2003b) and Martinez-Espineira and Nauges (2004)], Indonesia (Rietveld et al. (2000) and Cyprus (Hajispyrou et al. 2002), while flat rate structures are the primary form in France (Nauges and Thomas 2003) and Australia [see Thomas and Symer (1988), Barkatulla (1996), Dandy et al. (1997), Higgs and Worthington (2001) and Hoffman et al. (2006)]. This reflects, of course, the permissible and established tariff structures in these economies, rather than any real preference by water researchers.

In general, most of the literature on water management advocates the introduction of household metering (Yepes and Dianderas 1996; Dalhuisen et al. 2001; Bartoszczuk and Nakamori 2004; Dalhuisen and Nijkamp 2001). In fact, it has been suggested that the mere introduction of metering, regardless of the pricing structure used, results in a reduction in water use. For example, Yepes and Dianderas (1996) argue that the use of household metering can benefit system maintenance efforts. They found that unaccounted water represents around 10 to 15 percent of the water supply in high income countries, rising to over 50 percent in lower-income countries.

With metering the possibility arises to charge different prices to different customers based on the volume of water used. This can have important implications for social welfare. Consider an increasing block rate tariff. Whittington (1992), for instance, argues that increasing block rate tariffs are welfare reducing in developing countries. Two reasons are given: first, many high density apartments have only one meter, so the more families per apartment, the greater the chance of the total metered amount reaching the highest block prices. Whittington (1992) uses this evidence to argue for a low or zero-price tranche of water 
use per capita per household. It should be said, however, that metering, even in developed economies, is by no means universal. In Australia, for example, many local councils and water supply authorities still continue to explore the costs and benefits of installing individual household metering, especially in apartment blocks. All or parts of Norway, Ireland, the United Kingdom and Canada also remain residentially unmetered.

The remaining feature relates to the billing cycle. Obviously, for any given household and level of water consumption, billing frequency is inversely related to the cost per assessment. While the total water charge per year is unaffected, the difference lies in smaller, more frequent charges as against larger, lower frequency charges. The theoretical argument is that households are more aware of the impact on income of large bills and these can potentially reduce water consumption in subsequent periods. Frequent billing also reminds consumers more frequently of the fact that water costs. On the other hand, less frequent billing does not afford the opportunity for households to quickly adjust consumption in light of these larger bills. In general, billing frequency is little examined because of the low level of crosssectional and time-series variation. For example, most local government councils in Australia use a 90-day billing cycle corresponding to the quarterly rates assessment and this has changed little in recent years. Stevens et al. (1992) is one of the few studies to expressly model billing frequency, but found it to be statistically insignificant influence on water consumption. Griffin and Chang (1990) found a similar result when they attempted to account for rate changes in their model. Realistically, of course, the meaningful analysis of billing frequency can only be made in cross-sectional studies covering a range of utilities, and the overwhelming emphasis of past work on time-series in a single utility indicates why so little is known about this particular impact.

\section{Determinants of Demand}

\subsection{Pricing}

By the law of demand, residential water consumption should be inversely related to water price; as a commodity with few substitutes, the price elasticity of demand should also be inelastic. And where there is a single volumetric price (say, dollars per kilolitre), water demand estimation is relatively straightforward. Problematically, discontinuous tariff structures [that is, those that include a fixed access charge, with or without a 'free' water allowance, and/or a decreasing or increasing volumetric rate] do not lend themselves to classic econometric modelling techniques.

Consider, for example, a decreasing block rate structure where the price per unit of water falls as consumption increases: it is immaterial whether the price charged is 'stepped', with 
only a small number of decrements, or declines continuously (though the latter is clearly more complex). Since the marginal price varies according to consumption, this structure may introduce multiple price-quantity sets for a consumer tangent to their highest indifference curve, due to the budget line being convex to the origin. Because of this, estimates of price elasticity will vary (Hewitt and Hanemann, 1995). This applies not only to the case of multiple tariffs, but also those pricing schedules where a free allowance is involved. The latter effectively involves a zero price for the first block in an increasing block system. Stevens et al. (1992) chose to discard observations in zero price regions, while Dandy et al. (1997) used dummy variables to identify the presence of free water allowances. Where no free allowance is involved, empirical evidence indicates water consumption is positively related to the access charge, though its magnitude is very small [see, for instance, Hoglund (1999)]. The logical suggestion is higher water consumption is associated with higher costs of production and, in turn, higher access charges.

To overcome the problem more generally, it was proposed that an additional price variable reflecting the income effect imposed by decreasing or increasing rate block structures be included in water demand estimations. The concept of including a second price along with the marginal price was first introduced by Taylor (1975) (though in the context of electricity pricing). Taylor (1975) suggested that a single price variable, either the average or marginal price, was not sufficient. This approach was further developed by Nordin (1976) who introduced a difference variable referred to as the 'rate structure premium' defined as the difference between the total bill less what the bill would have been if the water quantity was consumed at the marginal price. The hypothesis is the rate structure premium should be able to capture the income effects of changes in the intramarginal prices, the fixed price and the quantity breakpoints. Nordin's (1976) premise was that consumers react not only to marginal prices, but also to the changes in consumer surplus as a result of moving from one block to the other, and that these intramarginal effects should be included in the demand equation. The difference variable in terms of consumer surplus is described as the difference in the consumer surplus under marginal pricing, and the consumer surplus that is actually experienced by a typical consumer. In case of increasing (decreasing) block tariffs the consumer surplus is larger (smaller) then if the units were purchased at the marginal price.

A large number of studies have specified Nordin's difference variable as a measure of price, including Chicoine et al. (1986), Chicoine and Ramamurthy (1986), Hewitt and Hanemann (1995), Barkatullah (1996), Renwick and Archibald (1998) and Martinez-Espinera (2003b). Chicoine et al. (1986), for example, concluded that the Nordin specification was largely unnecessary, recommending simple ordinary least squares (OLS) with marginal 
prices, even for block rate structures. Barkatullah (1996) disagreed, finding that OLS and instrumental variable (IV) models under multi-block tariffs are supportive of the Nordin theory. Arbués et al (2003), however, found that while the range of elasticity values can vary according to how price is specified, in many cases the difference was not noticeable. Stevens et al. (1992) also compared the price elasticity between increasing, flat and decreasing block tariff systems and concluded that calculated elasticities were not statistically different across the various price specifications. Finally, Espey's et al. (1997) meta-analysis concluded that studies using Nordin's difference variable yielded significantly higher estimates of elasticity than those specifying the marginal price alone.

Nordin's specification remains the subject of much controversy. This is because it is argued that while a perfectly-informed consumer should react to marginal price and the rate premium (as defined Nordin-style) most consumers do not devote the time or effort to study the structure or the change in intramarginal rates due to information costs (Nieswiadomy and Molina, 1991). Because of this, the Nordin specification (marginal price and difference) is argued to be significant in neither a statistical nor economic sense.

The essence of this argument is derived from Shin (1985). Shin (1985) suggested that the cause might be price illusion or incomplete information concerning the full budget constraint. Shin (1985) hypothesised that the coefficients of the rate structure premium and income variables should be equal in magnitude but opposite in sign because each measures a pure income effect: their coefficients in a linear demand equation should be equal. Certainly, the expected sign of income is positive, but the derivative of water use with respect to the difference is negative because increasing the intramarginal rates increases the difference and the implicit tax which reduces water use. To capture the pure income effect, Shin (1985) introduced yet another variable, the price perception variable, in addition to the marginal price. Shin's (1985) price perception model showed that consumers respond to average prices rather than marginal prices when faced with decreasing block rate structures. In early work, Nieswiadomy and Molina (1991) used a price perception model to compare increasing and decreasing block tariffs and found that customers react to marginal prices when facing increasing block rates and average prices when faced with decreasing block rates.

Across the remaining literature, there is a wide variation in price specification. Williams and Suh (1986), Moncur (1987), Nieswiadomy (1992) and Garcia and Reynaud (2003) specify marginal prices while Agthe and Billings (1980), Foster and Beattie (1981), Chicoine et al. (1986), Barkatullah (1996), Renwick et al. (1998) and Martínez-Espiñeira (2003b) adjust the marginal price with Nordin's difference. Carver and Boland (1980) specify the real price (adjusted for changes in the general price level; Gaudin et al. (2001) uses the average 
price, while Chicoine et al. (1986) and Griffin and Chang (1990) subtract the marginal price from the average price. Finally, Hajispyrou et al. (2002) employ the marginal price in the highest tariff block, while Schefter and David (1985) and Martínez-Espiñeira (2003a) use an average marginal price.

Certainly, the lack of variation in price elasticity estimates belies the substantial variation in price specification. Almost without exception, the estimated price elasticities are negative and inelastic (less than one), signifying the percentage reduction in the quantity of residential water demanded is less than proportionate to the percentage increase in price. While some estimates are very low - see Carver and Boland (1980), Thomas and Syme (1988), Barkatullah (1996), Renwick et al. (1998) and Martinez-Espinera and Nauges (2004) for price elasticities less than 0.25 - many more lie in the range of 0.25 to 0.75 - see Agthe and Billings (1980), Chicoine et al. (1986), Williams and Suh (1986), Nieswiadomy and Molina (1989), Nieswiadomy (1992), Pint (1999), Gaudin et al. (2001), Martinez-Espineira (2003a).

Reasons for the empirical variation in price elasticity estimates remain elusive. Espey's et al (1997) rather-dated meta-analysis at least removes some possible contenders: there is no significant difference between estimates from linear and log-linear models or least squares and other estimation techniques; and it appears to matter little if the sample uses household or aggregate (i.e. aggregated households, not aggregated industrial, commercial, agricultural and household users) data or specifies cross-sectional or time-series daily, monthly, quarterly or annual consumption. More likely prospects concern the failure of many studies to take into account market timing. For example, long-run price elasticity estimates are invariably more elastic than short run estimates [Agthe and Billings 1980; Carver and Boland 1980; Agthe et al 1986; Moncur 1987; Dandy et al. 1997; Martinez-Espinera 2003b; Nauges and Thomas (2003)] and winter price elasticity is less elastic then summer price elasticity (Dandy et al. 1997; Pint 1999; Gaudin et al. 2001). As justification, Arbués et al. (2003) suggest that longrun price responsiveness is likely to be greater due to the capital investment required by consumers to purchase water efficient appliances such as toilets, taps, showers and washing machines. Likewise, an estimate of price elasticity at the means can vary where there is income heterogeneity. For instance, Agthe and Billings (1987), Thomas and Syme (1988), Renwick and Archibald (1998) have concluded that the price elasticity of residential water demand is lower for low income households than middle and high income households. The other possibility is that because non-discretionary (or necessity) demands have a lower price elasticity than discretionary (or luxury) demands, the lower proportion of discretionary demands in low-income households infers lower price elasticities. 


\subsection{Income}

For normal goods, demand should increase proportionately with income. With water, the measurement of income effects on consumption is important, because water bills often represent a lower proportion of income for higher-income households (Arbués et al. 2003). In studies based on whole-of-utility data, income is normally per capita or per household, whereas in household-based studies actual household income (or a proxy such as housing value) can be employed. A further consideration is that income, through its correlation with education, may be reflective of water conservation measures taken by the household itself through the purchase of water-conserving appliances and planting of drought-tolerant garden vegetation. In addition, since income can approximate wealth, income (from taxation, census and survey data) can also be used to proxy other normal and luxury goods associated with household water consumption where data may not be as easily obtainable, including swimming pools and spas, in-ground garden irrigation systems, and dishwashing machines.

Estimates of income elasticity in the literature are almost universally income inelastic (less than one) and small in magnitude [see, for instance, Chicoine et al. (1986), Moncur (1987), Thomas and Symer (1988), Barkatullah (1996), Dandy et al. (1997), Gaudin et al. (2001), Garcia and Reynaud (2003). This appears consistent with the strong likelihood that the income elasticity of residential water demand is indeed low. But there is also the possibility that sample or specification bias may have a role to play. For example, few studies sample very income-diverse populations: the income elasticity of water demand would be higher with more variation in household income, say, between households in developing and developed economies. In addition, there is the aforementioned complication that increasing and decreasing block rates potentially encompass income effects. This may also serve to reduce the significance and magnitude of income effects. A final consideration is that the estimated income elasticities are short-run. Income-related activities like buying new appliances, moving house and house extensions, for example, that affect water demand, may only be possible over the longer term, so a more complex model allowing for this longer-run transition may be appropriate.

\subsection{Weather and seasonal factors}

Household water demand comprises two main components: non-discretionary and discretionary demand. Non-discretionary water use normally refers to basic needs such as drinking, cooking, bathing and toilet flushing. Discretionary water use is defined as all nonnecessitous uses. These would normally include outside uses like watering lawns and gardens, filling and topping-up swimming pools and washing cars, along with inside uses like choices 
relating to laundry and dishwashing appliances, showers and power showers (where a pump is used to boost the flow rate), spas and other luxury bathing uses. In general, and for obvious reasons, discretionary water use is regarded as being more price responsive than nondiscretionary water use.

As a rule, residential water use is usually shown to be highly sensitive to seasonal fluctuations. For example, Maidment and Miaou (1986) examined daily water use in nine US cities using a physics-type transfer function excluding price and income effects. They found that the response to rainfall depended first on its occurrence, and then on its magnitude, and that there is a non-linear response of water use to temperature changes: with no response for daily maximum air temperatures between $4-21^{\circ} \mathrm{C}$ and an increase in water use with temperatures above $21^{\circ} \mathrm{C}$. Further, water demand was hardly affected as consumption approached a subsistence level.

Weather and other seasonal factors have been specified in a number of ways. These range from temperature (Griffin and Chang 1990), minutes of sunshine, precipitation, rainfall, temperature and rainfall (Stevens et al. (1992), the number of rainy days (Hoffman et al. (2006), and even the evapo-transpiration rate of Bermuda grass less rainfall (Billings and Agthe 1980, Agthe et al. 1986, Nieswiadomy and Molina 1989 and Hewitt and Hanemann 1995). If the data frequency is at least semi-annual, the possibility also exists for seasonal variation, and dummy variables are generally used to control for summer and winter consumption. Without exception, summer price elasticities are lower than winter price elasticities, indicating that it is discretionary water that is most affected by behavioural changes.

Nonetheless, there has been some criticism surrounding the specification of weather parameters. Maidment and Miaou (1986) argue that the linear relationship assumed between the proxy for weather, such as rainfall, and the focus of measurement often breaks down. For example, the impact of rainfall diminishes over time and the effect is greater with higher levels of water use prior to rain. Likewise, Martínez-Espiñeira (2002) suggests that the mere occurrence of rain has a psychological impact, and so the number of rainy days rather than the amount of rain has a greater impact on water demand. Martínez-Espiñeira and Nauges (2004) also found that water demand is minimally affected by weather as consumption approaches some base (non-discretionary) level of use. Finally, in their meta-analysis, Espey et al (1997) and Dalhuisen et al. (2003) argued that the incorporation of rainfall results in significantly less elastic estimates of the price elasticity of demand. At first sight this would suggest some rainfall and prices are positively related, lying at odds with the notion that prices should be set with scarcity in mind. 


\subsection{Population and household composition}

If the dependent variable is defined as water usage per household, household size should be positively associated with water use. However, not all studies have included household size, even when considering average household water consumption (Agthe and Billings 1980; Nieswiadomy 1992). Accordingly, there is remarkably little empirical evidence on scale economies in water consumption, though the evidence that does exist is very strong. Arbués et al. (2000), for example, found that the increase in water use is often less than proportional to the increase in household size or population. They postulated that an increase in the number of households, with population held constant, would lead to an increase in the total water demand in an area. In the same way, an increase in population in inner city and other densely populated areas is unlikely to be associated with an increase in consumption due to smaller housing lots, smaller gardens, and a higher predominance of flats and units. However, in countries where garden-related use is not strong, the extra in-house use (washing, bathing, etc.) would tend to dominate.

A further consideration is household composition. Nauges and Thomas (2000), for example, argued that water consumption in areas with a higher proportion of younger persons is likely to be higher due to more frequent laundering and use of water-intensive outdoor leisure activities. However, communities with a higher proportion of older inhabitants may be more focused on gardening. Martinez-Espineira (2003a), for instance, included variables reflecting both the proportion of the population over 64 years and those under 19 years. In addition, people from different cultural backgrounds may be more or less reactive to the price of water. Griffin and Chang (1990) and Gaudin et al. (2001) specified the percentage of the population of Spanish origin as a determinant in their study of water consumption in Texas.

\subsection{Non-price consumption controls}

In terms of demand-side management policies, a number of non-price controls on consumption are possible. These can include prohibitions and restrictions on the watering of gardens, filling of swimming pools, car washing and path and building cleaning. However, they also include appeals for water conservation and education campaigns aimed at limiting water use. Because of the ubiquitous nature of these policies and their possible interaction with other variables, especially pricing, there is the requirement to include some specification in analyses of water demand and consumption (Syme et al. 2000). Renwick, et al. (1998), for instance, argue that the clear definition of all relevant policy variables is important for accurate measurement since the nature of the policies used may vary either through time or cross-sectionally. 
Syme et al. (2000) have argued that the possible interactions of non-price campaigns with other policy instruments make it difficult to evaluate their effectiveness. Statistical studies using regression have problems with multicollinearity among the variables. Interpretation is also a problem, possibly due to unmeasured exogenous variables; for example, a marketing campaign may heighten the motivation to respond to the pricing schedule. Interestingly, while feedback information on usage has been shown to reduce energy consumption, it appears to make little difference to water consumption. Possible causes given are: ineffective conservation methods, water saving is more difficult, water is too cheap to worry about and a lack of motivation to save (Thomas and Syme, 1988).

\section{Data and Sampling Frequency}

The availability (or rather acute lack) of accurate data at an appropriate frequency has plagued attempts at modelling residential water demand. In theory, estimating residential water demand functions with household level data would be the most valuable, especially consistently over time. But while many researchers advocate the use of household level surveys to specifically identify and measure all relevant household characteristics, only a few have actually been conducted, comprising Foster and Beattie (1981), Nieswiadomy (1992), Nieswiadomy and Cobb (1993), Higgs and Worthington (2001), Arbues et al. (2001), and Hajispyrou et al. (2002). As an alternative, Rizaiza (1991) and Renwick and Archibald (1998) used stratified random sampling of surveys.

The lack of data availability may help explain the high rate of data re-use from previously published work. For example, the 1974-1980 data for Tucson, Arizona first used in Agthe and Billings (1980) was later specified in Billings and Agthe (1980), Agthe et al. (1986) and Agthe and Billings (1987), while a 1976-1985 Denton, Texas dataset was repeatedly employed in Nieswiadomy and Molina (1989; 1991), Griffin and Chang (1990), Hewitt and Hanemann (1995) and Gaudin et al. (2001). This is problematic in that much of an apparently broad literature is, in reality, reliant on only a few unique datasets. That said, and as shown in Table 1, the estimates are generally consistent, despite the dissimilar approaches, and this yields some insight into the relatively (low) impact of specification change. At the same time, the cost of gathering information means that many other studies rely on rather-dated information. For example, Carver and Boland (1980) specified a 1969-1974 Washington panel, Foster and Beattie (1981) used a US cross-section from 1960, Moncur (1987) examined a 1975-1981 Hawaiian panel, and Timmins (2002) used a 1970-1993 Californian panel. Given the rapid change in charging regimes and conditions, these studies may not have much to offer contemporary policymakers and utility managers. 
Outside of the household-level surveys, most existing research has focused instead on aggregated mains, community or utility-level data [see, for example, Thomas and Syme (1988), Stevens et al. (1992), Nieswiadomy and Cobb (1993), Barkatullah (1996), Timmins (2002)]. However, this brings additional complications. One concerns the need for matching average water consumption with the averages of other demand-related characteristics, often from different sources with different frequencies. These potentially include household income, household size, household demographics, etc. The more substantive complication is the apparent inconsistency between non-price demand factors and the quantity demanded being expressed in averages, while water prices are almost always in marginal terms. Schefter and David (1985) argued that on this basis, the more accurate price measures are the mean marginal price and the mean (Nordin) difference (emphasis added).

Pooled time-series, cross-sectional (or panel data) techniques have dominated the literature [see, for instance, Agthe and Billings (1980), Chicoine and Ramamurthy (1986), Hewitt and Hanemann (1995), Dandy et al. (1997), Gaudin et al. (2001), Martinez-Espineira (2003a)]. But while the stability of estimates and the increasing degrees of freedom offered by panel data are well known, most of these are unbalanced panels of aggregated communities and utilities, with none following specific households over time. Cross-sectional techniques are the next most popular [see Foster and Beattie (1981), Chicoine et al. (1986), Martin and Thomas (1986), Stevens et al. (1992), Rietveld et al. (2000) and Hajispyrou et al. (2002). And not surprisingly given the difficulty in gather accurate and consistent data, time series techniques have not been well used. Further, there is little evidence of application of some of the more advanced time-series techniques [for an exception see Martinez-Espinera (2003)].

The question also arises as to how these studies treat periods when demands exceed supplies, such as droughts, and cannot be completely satisfied. For the most part, the literature includes these periods and relies on factors such as rainfall and water restrictions to quantify these impacts. The alternative, excluding periods when supplies actually meet demands, is not found and the implication is that some misspecification in the estimation of the parameters may result.

\section{Estimation Techniques}

The existing literature on the estimation of the water demand models involves numerous econometric techniques. For cross-sectional data, the empirical techniques employed include ordinary least squares (OLS), generalised least squares (GLS), two and three-stage least squares (2SLS and 3SLS), logit and instrumental variables (IV). In terms of time series data, vector autoregressive (VAR) models and cointegration techniques could also be potentially 
used, however the only known water demand study to do so is Martínez-Espiñeira (2003b). Lastly, many techniques normally reserved for cross-sectiosn are equally applicable to pooled time-series, cross-sectional (or panel) data, including OLS, GLS, maximum-likelihood (ML) and 2SLS.

That said ordinary least squares methods dominate the water demand literature (Billings and Agthe 1980; Chicoine et al 1986; Hewitt and Hanemann 1995; Higgs and Worthington 2001 and Martínez-Espiñeira 2003a). But one particular problem when using data with block rate pricing is simultaneity: that is, when consumers select the quantity of water to be demanded, they also select the price. Since the price of water both determines and is determined by consumption, OLS estimation of block rate pricing models may yield biased and inconsistent estimates. Since there is a need to find a proxy for the stochastic variable price, several IV techniques have been suggested.

Nieswiadomy and Molina (1991) focus on two common approaches. The first introduces a separate price equation in a two stage least squares (2SLS) procedure. In the first stage, the observed price is regressed against all explanatory variables during the increasing blockpricing period. The predicted price is then specified in the second stage as a regressor. Nieswiadomy and Molina's (1991) second approach involves the regression of the observed water demand on the actual price that the household faces at different levels of water demand. In the second stage, the predicted quantity demanded and the actual rate schedule is used to obtain a predicted price (Agthe et al 1986; Agthe and Billings 1987; Barkatullah 1996; Hewitt and Hanemann 1995 and Higgs and Worthington 2001). Regardless, both techniques are likely to improve the reliability of estimates.

Within the many other techniques, a variety of functional forms have been employed, some with allowance for non-linearity in the underlying consumption technologies. While linear demand functions are easy to estimate, there is the implication that the change in quantity demanded in response to a price change is the same at every price level. Another form, the Cobb-Douglas function, is synonymous with the non-linear log-log (or double-log) model. One of the well-known properties of Cobb-Douglas is that the estimated slope coefficient represents the (partial) elasticity of the dependent variable with respect to the independent variable, holding all other independent variables constant. This removes the necessity of calculating partial elasticities at the means, as with linear functions. CobbDouglas water demand equations are widely used in the literature, including Foster and Beattie (1981), Nieswiadomy and Cobb (1993), Hewitt and Hanemann (1995) and Garcia and Reynaud (2004). Alternatively, Gaudin et al. (2001) and Martínez-Espiñeira and Nauges (2004) have employed the alternative Stone-Geary utility function, which is also non-linear, 
though log-lin. The main advantage of this form is that it can incorporate some minimum amount of water demand, irrespective of prices. This subsistence level may be made dependent on the evolution of consumer habits and stock of physical capital, in such a way that its size varies with time.

\section{Concluding Remarks}

The primary focus of residential water demand modelling has been on obtaining consistent, reliable and useful measures of the price (and, to a lesser extent, income) elasticity of demand. Price elasticity estimates are generally found in the range of zero to 0.5 in the shortrun and 0.5 to unity in the long-run: income elasticity estimates are of a much smaller magnitude (usually) and positive. The income elasticity of residential water may well be low; sample or specification bias, however, may also be important. For instance, the income effects as measured may be mixed up with price effects in poorly specified models or the elasticities are really only valid in the short term, and may be substantially more elastic over the longer term. Further, price elasticities are found to be higher in the summer than the winter and price elasticities are generally highest where outside (read discretionary) water usage is highest (including lawn and garden watering, car washing and swimming pools). The demand for water has also been shown to vary with seasonal factors, household composition, and the imposition of water restrictions. Finally, aggregate and household level data have been shown to yield fairly similar results. These are the least contentious aspects of this area of research.

A more contentious aspect concerns price specification, of which two dimensions have been recognized. First, most water tariffs have complex structures that combine fixed and variable charges. Because of this, there is a division placed between marginal and average prices and consumers' reaction to these prices will then depend on price perception. Second, an additional complication arises where modelling techniques are required to compensate for the (potential) income effect of variable block tariffs. Simultaneity is the basic issue, as consumers choose quantity-price pairs: that is, decisions on quantity determine prices. But specification is only part of the story. The most fundamental limitation in this area is the lack of data concerning households and their demands for water. Only with consistent and specific information collected over relatively long periods of time in a variety of jurisdictions will it be possible to definitively model the many influences on residential water consumption as an input into residential water policy.

Certainly, there is an urgent, even dire, need for empirical work in this area. Consider Australia where there is growing disquiet that the worst drought since 1788 and record high 
temperatures are not part of some natural cycle, rather the longer realignment in rainfall and temperature caused by global warming. With reservoirs in nearly all state capitals at critically low levels, a lack of essential infrastructure, consideration of desalination plants and effluent recycling plants, and the reallocation of water allocations from agriculture to urban use already taking place, residential water demand management appears the only short-term solution. Patently, good water demand modelling is the key to good water policymaking.

\section{Acknowledgements}

The authors would like to thank the editor, Colin Roberts, and two anonymous referees for their helpful comments on an earlier version of this paper. The financial assistance of the Queensland Department of Natural Resources and Mines is also gratefully acknowledged.

\section{References}

Agthe, D. and Billings R. (1980). Dynamic models of residential water demand. Water Resource Research 16: 476-480.

Agthe, D., Billings, R., Dobra, J. and Rafiee, K. (1986). A simultaneous equation demand model for block rates. Water Resources Research 22: 1-4.

Agthe, D. and Billings, R. (1987). Equity, price elasticity, and household income under increasing block rates for water. American Journal of Economics and Sociology 46: 273-286

Arbués, F., Barberan, R. and Villanua, I. (2000). Water price impact on residential water demand in the city of Zaragoza: A dynamic panel data approach. Paper presented at the $40^{\text {th }}$ European Congress of the European Regional Studies Association in Barcelona, 30-31 August.

Arbués, F., García-Valiñas, M. and Martínez-Espiñeira, R. (2003). Estimation of residential water demand: A state of the art review. Journal of Socio-Economics 32: 81-102.

Barkatullah, N. (1996). OLS and instrumental variable price elasticity estimates for water in mixed-effects model under multiple tariff structure, Report No. 226, Department of Economics, University of Sydney.

Bartoszczuk, P. and Nakamori, Y. (2004). Modelling sustainable water prices. In M.Quaddus and A. Siddique (eds.) Handbook of Sustainable Development Planning: Studies in Modelling and Decision Support. Cheltenham: Edward Elgar.

Billings, B. and Agthe, D. (1980). Price elasticities for water: A case of increasing block rates. Land Economics 56: 73-84.

Carver, P. and Boland, J. (1980). Short run and long run effects of price on municipal water use. Water Resources Research 16: 609-616

Chicoine, D. and Ramamurthy, G. (1986). Evidence on the specification of price in the study of domestic water demand. Land Economics 62: 26-32.

Chicoine, D., Deller, S. and Ramamurthy, G. (1986). Water demand estimation under block rate pricing: A simultaneous equation approach. Water Resources Research 22: 859-63.

Dalhuisen J., de Groot, H. and Nijkamp, P. (2001). Thematic report on the economics of water in metropolitan areas, European Commission: Environment and Climate Programme, DG XII, Human Dimension of Environmental Change: Metropolitan Areas and Sustainable Use of Water. Available at: http://www.feweb.vu.nl/.

Dalhuisen, J. and Nijkamp, P. (2001). The economics of $\mathrm{H}_{2} \mathrm{O}$. In Conference Proceedings: Economic Instruments and Water Policies in central and Eastern Europe: Issues and Options, Szetendre, Hungary, Available at: http://www.rec.org/.

Dalhuisen, J., Florax, R. de Groot, H. and Nijkamp, P. (2003). Price and income elasticities of residential water demand: A meta-analysis. Land Economics 79: 292-308.

Dandy, G., Nguyen, T. and Davies, C. (1997). Estimating residential water demand in the presence of free allowances. Land Economics 73: 125-139.

Dinar, A. and Subramanian, A. (1998). Policy implications from water pricing in various countries. Water Policy 1: 239-250.

Espey, M., Espey, J. and Shaw, W.D. (1997). Price elasticity of residential demand for water: A meta-analysis. Water Resources Research 33: 1369-74.

Foster, H. and Beattie, B. (1981). On the specification of price in studies of consumer demand under block price scheduling. Land Economics 57: 624-629. 
Garcia, S. and Reynaud, A. (2003). Estimating the benefits of efficient water pricing in France. Journal of Resource and Energy Economics 26: 1-25.

Gaudin, S. (2006). Effect of price information on residential water demand. Applied Economics 38: 383-393

Gaudin, S., Griffin, R. and Sickles, R. (2001). Demand specification for municipal water management: Evaluation of the Stone-Geary form. Land Economics 77: 399-422

Griffin, R. and Chang, C. (1990). Pre-test analyses of water demand in thirty communities. Water Resources Research 26: 2251-2255.

Hadjispirou, S., Koundouri, P. and Pashardes, P. (2002). Household demand and welfare implications of water pricing in Cyprus. Environment and Development Economics 7: 659-685.

Hewitt, J. and Hanemann, W. (1995). A discrete/continuous choice approach to residential water demand under block rate pricing. Land Economics 71: 173-192.

Higgs, H. and Worthington, A. (2001). Consumer preferences and charging options in a large urban municipality: A case study. Public Works Management and Policy 5: 209-207.

Hoffman, M., Worthington, A.C. and Higgs, H. (2006). Urban water demand with fixed volumetric charging in a large municipality: The case of Brisbane, Australia. Australian Journal of Agricultural and Resource Economics 50: 347-359

Hoglund, L. (1999) Household demand for water in Sweden with implications of a potential tax on water use. Water Resources Research 35: 3853-63.

Klawitter, S. (2003). A methodical approach for multi criteria sustainability assessment of water pricing in urban areas. Paper presented at the 2003 Berlin Conference on the Human Dimensions of Global Environmental Change. Available at: http://www.fu-berlin.de/.

Maidment, D.R. and Miaou, S.P. (1986). Daily water use in nine cities. Water Resources Research 22: 845-851.

Martin, W. and Thomas, J. (1986). Policy relevance in studies of residential water demand. Water Resources Research 22: 1735-1741

Martínez-Espiñeira, R. (2002). Residential water demand in the northwest of Spain. Environmental and Resource Economics 21: 161-187.

Martínez-Espiñeira, R. (2003a). Estimating water demand under increasing-block tariffs using aggregate data and proportions of users per block. Environmental and Resource Economics 26: 5-23.

Martínez-Espiñeira, R. (2003b). An estimation of residential water demand using co-integration and error correction techniques, Working Papers, St. Francis Xavier University, Canada. Available at: http://www.stfx.ca/.

Martínez-Espiñeira, R. and Nauges, C. (2004). Is really all domestic water consumption sensitive to price control? Applied Economics 36: 1697-1703.

Moncur, J. (1987). Urban water pricing and drought management. Water Resources Research 23: 393-398.

Nauges, C. and Blundell, R. (2002). Estimating residential water demand under block rate pricing: A nonparametric approach. Working Paper, Laboratoire d'Economie de l'Environnement et des Ressources Naturelles (LEERNA), Unité Mixte de Recherche de l'Institut National de la Recherche Agronomique (INRA), Et de l'Université des Sciences Sociales de Toulouse.

Nauges, C. and Thomas, A. (2000). Privately operated water utilities, municipal price negotiation, and estimation of residential water demand: The case of France. Land Economics 76: 68-85.

Nauges, C. and Thomas, A. (2003). Long-run study of residential water consumption. Environmental and Resource Economics 26: 25-43.

Nieswiadomy, M. and Cobb, S. (1993). Impact of pricing structure selectivity on urban water demand. Contemporary Policy Issues 11: 101-113.

Nieswiadomy, M. and Molina, D. (1989). Comparing residential water demand estimates under decreasing and increasing block rates using household data. Land Economics 65: 280-289.

Nieswiadomy, M. and Molina, D. (1991). A note on price perception in water demand models. Land Economics 67: 352-359.

Nieswiadomy, M. (1992). Estimating urban residential water demand: Effects of price structure, conservation, and education. Water Resources Research 28: 609-615.

Nordin, J.A. (1976). A proposed modification of Taylor's demand analysis: Comment. Bell Journal of Economics 7: 719-721.

Pint, E. (1999). Household responses to increased water rates during the California drought. Land Economics 75 : 246-266.

Renwick, M. and Archibald, S. (1998). Demand side management policies for residential water use: Who bears the conservation burden? Land Economics 74: 343-359.

Renwick, M. and Green, R. (2000). Do residential water demand side management policies measure up? An analysis of eight California water agencies. Journal of Environmental Economics and Management 40: 37-55.

Renwick, M., Green, R. and McCorkle, C. (1998). Measuring The Price Responsiveness Of Residential Water Demand In California’s Urban Areas. Report Prepared for the California Department of Water Resources, May 1998. Available at: http://rubicon.water.ca.gov/.

Rietveldt, P., Rouwendal, J. and Zwart, B. (2000). Block rate pricing of water in Indonesia: An analysis of welfare effects. Bulletin of Indonesian Economic Studies 36: 73-92. 
Rizaiza, O. (1991). Residential water usage: A case study of the major cities of the Western region of Saudi Arabia. Water Resources Research 27: 667-671.

Schefter, J. and David, E. (1985). Estimating residential water demand under multi-part tariffs using aggregate data. Land Economics 61: 272-280.

Stevens, T.H., Miller, J. and Willis, C. (1992). Effect of price structure on residential water demand. Water Resources Bulletin 28: 681-685.

Syme, G., Nancarrow, B. and Seligman, C. (2000). The evaluation of information campaigns to promote voluntary household water conservation. Evaluation Review 24: 539-578.

Taylor, L.D. (1975). The demand for electricity: A survey. Bell Journal of Economics 6: 74-110.

Thomas, F. and Syme, G. (1988). Estimating residential price elasticity of demand for water; A contingent valuation approach. Water Resource Research 24: 1847-1857.

Timmins, C. (2002). Measuring the dynamic efficiency costs of regulators preferences: municipal water utilities in the arid West. Econometrica 70: 603-629.

Whittington, D. (1992). Possible adverse effects of increasing block water tariffs in developing countries. Economic Development and Cultural Change 41: 75-87.

Williams, M. and Suh, B. (1986). The demand for urban water by customer class. Applied Economics 18: 12751289.

Yepes, G. and Dianderas A. (1996). Water and Wastewater Utilities Indicators. $2^{\text {nd }}$ Ed. Water and Sanitation Division, World Bank. Available at: http://www.worldbank.org/. 
TABLE 1. Empirical Analyses of Residential Water Demand

\begin{tabular}{|c|c|c|c|c|c|c|c|c|c|}
\hline Author(s) & Data & Sample & $\begin{array}{l}\text { Pricing } \\
\text { structure }\end{array}$ & $\begin{array}{l}\text { Dependent } \\
\text { variable(s) }\end{array}$ & Independent variables & $\begin{array}{l}\text { Estimation } \\
\text { technique(s) }\end{array}$ & $\begin{array}{c}\text { Price } \\
\text { elasticity }\end{array}$ & $\begin{array}{l}\text { Income } \\
\text { elasticity }\end{array}$ & Other findings \\
\hline $\begin{array}{l}\text { Agthe and } \\
\text { Billings } \\
\text { (1980) }\end{array}$ & Panel. & $\begin{array}{l}\text { Tucson, } \\
\text { Arizona, } \\
\text { 1974-1980. }\end{array}$ & $\begin{array}{l}\text { Increasing } \\
\text { block and } \\
\text { flat rate }\end{array}$ & $\begin{array}{l}\text { Monthly } \\
\text { household water } \\
\text { consumption. }\end{array}$ & $\begin{array}{l}\text { Marginal price, difference price, evaporation } \\
\text { rate of Bermuda grass less rainfall, household } \\
\text { income. }\end{array}$ & OLS & $\begin{array}{l}\text { Short-run } \\
0.18-0.36 \text {; } \\
\text { long-run } \\
0.27-0.50\end{array}$ & $\begin{array}{l}\text { Short-run } \\
1.33-2.07 ; \\
\text { long-run } \\
1.97-2.77\end{array}$ & $\begin{array}{l}\text { Linear model elasticities } \\
\text { greater than log-log model. }\end{array}$ \\
\hline $\begin{array}{l}\text { Billings and } \\
\text { Agthe (1980) }\end{array}$ & Panel. & $\begin{array}{l}\text { Tucson, } \\
\text { Arizona, } \\
\text { 1974-1977. }\end{array}$ & $\begin{array}{l}\text { Increasing } \\
\text { block rate. }\end{array}$ & $\begin{array}{l}\text { Monthly } \\
\text { household water } \\
\text { consumption. }\end{array}$ & $\begin{array}{l}\text { Marginal price (nominal and real), difference } \\
\text { term, implicit marginal sewer charge during } \\
\text { winter months, personal income, } \\
\text { evapotranspiration less rainfall }\end{array}$ & OLS & $0.27-0.49$ & n.a. & $\begin{array}{l}\text { Real monetary values produce } \\
\text { substantially } \\
\text { statistical results tronger } \\
\text { unadjusted prices and incomes. }\end{array}$ \\
\hline $\begin{array}{l}\text { Carver and } \\
\text { Boland } \\
(1980)\end{array}$ & Panel. & $\begin{array}{l}\text { Washington, } \\
\text { 1969-1974. }\end{array}$ & $\begin{array}{l}\text { Increasing } \\
\text { block rate. }\end{array}$ & $\begin{array}{l}\text { Average annual } \\
\text { water } \\
\text { production } \\
\text { divided by the } \\
\text { number of } \\
\text { connections. }\end{array}$ & $\begin{array}{l}\text { Real income, real price, average number of } \\
\text { residences per connection, average number of } \\
\text { employees per connection, lagged } \\
\text { consumption. }\end{array}$ & OLS & $\begin{array}{l}\text { Short-run } \\
0.10 \text {; long- } \\
\text { run } 0.02- \\
0.70\end{array}$ & n.a. & $\begin{array}{l}\text { When separated into seasonal } \\
\text { and non-seasonal components, } \\
\text { elasticities are substantially } \\
\text { more inelastic. }\end{array}$ \\
\hline $\begin{array}{l}\text { Foster and } \\
\text { Beattie } \\
(1981)\end{array}$ & $\begin{array}{l}\text { Cross- } \\
\text { sectional }\end{array}$ & $\begin{array}{l}\text { United States, } \\
1960 .\end{array}$ & $\begin{array}{l}\text { Increasing } \\
\text { and } \\
\text { decreasing } \\
\text { block rates }\end{array}$ & $\begin{array}{l}\text { Average yearly } \\
\text { household water } \\
\text { consumption }\end{array}$ & $\begin{array}{l}\text { Marginal price, difference price, median } \\
\text { household income, precipitation, average } \\
\text { number of residents per meter. }\end{array}$ & OLS & 0.12 & 0.58 & $\begin{array}{l}\text { Results of a Nordin-type } \\
\text { marginal price model suggest } \\
\text { average price is a better } \\
\text { specification for yearly data. }\end{array}$ \\
\hline $\begin{array}{l}\text { Schefter and } \\
\text { David (1985) }\end{array}$ & $\begin{array}{l}\text { Cross- } \\
\text { sectional }\end{array}$ & $\begin{array}{l}\text { Wisconsin, } \\
1997 .\end{array}$ & $\begin{array}{l}\text { Increasing } \\
\text { and } \\
\text { decreasing } \\
\text { block rates }\end{array}$ & $\begin{array}{l}\text { Quantity of } \\
\text { water delivered } \\
\text { to residential } \\
\text { users }\end{array}$ & $\begin{array}{l}\text { Mean marginal price estimated using the } \\
\text { combined water and sewer tariffs, mean } \\
\text { difference using the combined water and } \\
\text { sewer tariffs, average household income; }\end{array}$ & OLS & n.a. & n.a. & $\begin{array}{l}\text { Given aggregate data, mean } \\
\text { marginal price and mean price } \\
\text { difference are the most } \\
\text { appropriate. }\end{array}$ \\
\hline $\begin{array}{l}\text { Chicoine, } \\
\text { Deller and } \\
\text { Ramamurthy } \\
\text { (1986) }\end{array}$ & $\begin{array}{l}\text { Cross- } \\
\text { sectional }\end{array}$ & $\begin{array}{l}\text { Illinois, } \\
1983 .\end{array}$ & $\begin{array}{l}\text { Decreasing } \\
\text { block rate. }\end{array}$ & $\begin{array}{l}\text { Monthly } \\
\text { household water } \\
\text { consumption. }\end{array}$ & $\begin{array}{l}\text { Price index for other relevant goods, income, } \\
\text { Nordin's difference (rate premium), marginal } \\
\text { price, average price less marginal price. }\end{array}$ & $\begin{array}{l}\text { OLS, 2SLS } \\
\text { and 3SLS }\end{array}$ & $0.22-0.42$ & $0.01-0.14$ & $\begin{array}{l}\text { 3SLS estimates slightly more } \\
\text { efficient compared to 2SLS } \\
\text { estimates and consistent with } \\
\text { OLS. }\end{array}$ \\
\hline $\begin{array}{l}\text { Agthe, } \\
\text { Billings, } \\
\text { Dobra and } \\
\text { Rafiee (1986) }\end{array}$ & Panel. & $\begin{array}{l}\text { Tucson, } \\
\text { Arizona, } \\
\text { 1974-1980. }\end{array}$ & $\begin{array}{l}\text { Increasing } \\
\text { block rate. }\end{array}$ & $\begin{array}{l}\text { Monthly } \\
\text { household water } \\
\text { consumption. }\end{array}$ & $\begin{array}{l}\text { Marginal price, rate structure premium, } \\
\text { evaporation rate of Bermuda grass less } \\
\text { rainfall, household income. }\end{array}$ & $\begin{array}{l}\text { OLS, IV and } \\
\text { SE }\end{array}$ & $\begin{array}{l}\text { Short-run } \\
0.14 \text {; long- } \\
\text { run } 0.62\end{array}$ & n.a. & $\begin{array}{l}\text { Demand is significantly more } \\
\text { elastic in long run than in short } \\
\text { run. }\end{array}$ \\
\hline
\end{tabular}




\begin{tabular}{|c|c|c|c|c|c|c|c|c|c|}
\hline Author(s) & Data & Sample & $\begin{array}{l}\text { Pricing } \\
\text { structure }\end{array}$ & $\begin{array}{l}\text { Dependent } \\
\text { variable(s) }\end{array}$ & Independent variables & $\begin{array}{l}\text { Estimation } \\
\text { technique(s) }\end{array}$ & $\begin{array}{l}\text { Price } \\
\text { elasticity }\end{array}$ & $\begin{array}{l}\text { Income } \\
\text { elasticity }\end{array}$ & Other findings \\
\hline $\begin{array}{l}\text { Martin and } \\
\text { Thomas } \\
\text { (1986) }\end{array}$ & $\begin{array}{l}\text { Cross- } \\
\text { sectional }\end{array}$ & $\begin{array}{l}\text { Kuwait, South } \\
\text { Australia, } \\
\text { Western } \\
\text { Australia, } \\
\text { Arizona, } \\
\text { 1978/79 and } \\
\text { 1981/82. }\end{array}$ & $\begin{array}{l}\text { Various } \\
\text { volumetric } \\
\text { charging } \\
\text { systems. }\end{array}$ & $\begin{array}{l}\text { Mean daily per } \\
\text { capita water } \\
\text { consumption. }\end{array}$ & Marginal price. & $\begin{array}{l}\text { Geometric } \\
\text { analysis of } \\
\text { price and } \\
\text { quantity } \\
\text { pairs }\end{array}$ & 0.50 & n.a. & $\begin{array}{l}\text { Precise estimates of demand } \\
\text { elasticities may not be } \\
\text { necessary for policy purposes. } \\
\text { Short-run elasticities give little } \\
\text { information for policy } \\
\text { purposes. }\end{array}$ \\
\hline $\begin{array}{l}\text { Chicoine and } \\
\text { Ramamurthy } \\
\text { (1986) }\end{array}$ & Panel. & $\begin{array}{l}\text { Illinois, } \\
1983 .\end{array}$ & $\begin{array}{l}\text { Decreasing } \\
\text { block rate }\end{array}$ & $\begin{array}{l}\text { Monthly water } \\
\text { consumption by } \\
\text { household }\end{array}$ & $\begin{array}{l}\text { Average price decomposed into a marginal } \\
\text { price, monthly income less the effects of the } \\
\text { block rate structure (Nordin), number of } \\
\text { persons in household, number of bath rooms, } \\
\text { dummies for month. }\end{array}$ & OLS & n.a. & n.a. & $\begin{array}{l}\text { The marginal price or average } \\
\text { price are, by themselves, } \\
\text { inadequate in explaining } \\
\text { consumption demand for rural } \\
\text { domestic water. }\end{array}$ \\
\hline $\begin{array}{l}\text { Agthe and } \\
\text { Billings } \\
\text { (1987) }\end{array}$ & Panel. & $\begin{array}{l}\text { Tucson, } \\
\text { Arizona, } \\
\text { 1974-1980. }\end{array}$ & $\begin{array}{l}\text { Increasing } \\
\text { block rate }\end{array}$ & $\begin{array}{l}\text { Monthly } \\
\text { household water } \\
\text { consumption. }\end{array}$ & $\begin{array}{l}\text { Marginal price, difference price, evaporation } \\
\text { rate of Bermuda grass less rainfall, household } \\
\text { income, presence of swimming pool, type of } \\
\text { yard vegetation, number of persons in } \\
\text { household. }\end{array}$ & $\begin{array}{l}\text { 2SLS and } \\
\text { IV }\end{array}$ & $\begin{array}{l}\text { Low } \\
\text { income } \\
0.56 ; \\
\text { middle } \\
0.49 ; \text { upper } \\
\text { middle } \\
0.46 \text {; high } \\
0.40\end{array}$ & n.a. & $\begin{array}{l}\text { Substantial increase in water } \\
\text { use as household income rises. }\end{array}$ \\
\hline $\begin{array}{l}\text { Thomas and } \\
\text { Syme (1988) }\end{array}$ & $\begin{array}{l}\text { Cross- } \\
\text { sectional. }\end{array}$ & $\begin{array}{l}\text { Perth, } \\
\text { Western } \\
\text { Australia, } \\
1982 .\end{array}$ & Flat rate. & $\begin{array}{l}\text { Annual water } \\
\text { consumption } \\
\text { from public } \\
\text { mains supply. }\end{array}$ & $\begin{array}{l}\text { Marginal price, difference variable, average } \\
\text { household income, annual precipitation, } \\
\text { restrictions on public water supply use, hours, } \\
\text { average household size, percentage of } \\
\text { households which use a private underground } \\
\text { water bore. }\end{array}$ & OLS & $\begin{array}{l}\text { Overall } \\
0.18 ; \\
\text { low income } \\
0.19 ; \\
\text { middle } \\
0.18 ; \text { high } \\
0.13\end{array}$ & $0.20-0.22$ & $\begin{array}{l}\text { Contingent valuation approach } \\
\text { appears to be reliable and } \\
\text { applicable where the available } \\
\text { data do not favour regression } \\
\text { analysis. }\end{array}$ \\
\hline
\end{tabular}




\begin{tabular}{|c|c|c|c|c|c|c|c|c|c|}
\hline Author(s) & Data & Sample & $\begin{array}{c}\text { Pricing } \\
\text { structure }\end{array}$ & $\begin{array}{l}\text { Dependent } \\
\text { variable(s) }\end{array}$ & Independent variables & $\begin{array}{c}\text { Estimation } \\
\text { technique(s) }\end{array}$ & $\begin{array}{c}\text { Price } \\
\text { elasticity }\end{array}$ & $\begin{array}{l}\text { Income } \\
\text { elasticity }\end{array}$ & Other findings \\
\hline $\begin{array}{l}\text { Nieswiadomy } \\
\text { and Molina } \\
\text { (1989) }\end{array}$ & Panel. & $\begin{array}{l}\text { Denton, } \\
\text { Texas, } \\
1976-1985 .\end{array}$ & $\begin{array}{l}\text { Increasing } \\
\text { and } \\
\text { decreasing } \\
\text { block rates. }\end{array}$ & $\begin{array}{l}\text { Monthly } \\
\text { household } \\
\text { consumption. }\end{array}$ & $\begin{array}{l}\text { One-month lagged water consumption, } \\
\text { monthly income (based on house value), } \\
\text { marginal block price, ratio of lagged average } \\
\text { monthly price to current marginal price, } \\
\text { irrigable land, weather (based on } \\
\text { evapotranspiration of Bermuda grass less } \\
\text { precipitation). }\end{array}$ & $\begin{array}{l}\text { OLS, IV and } \\
\text { 2SLS }\end{array}$ & $0.36-0.55$ & $0.14-0.15$ & $\begin{array}{l}\text { Significant price effects with } \\
\text { decreasing and increasing } \\
\text { block rates. } \\
\text { Consumers react to average } \\
\text { price under decreasing block } \\
\text { and marginal price under } \\
\text { increasing block. }\end{array}$ \\
\hline $\begin{array}{l}\text { Stevens, } \\
\text { Miller and } \\
\text { Willis (1992) }\end{array}$ & $\begin{array}{l}\text { Cross- } \\
\text { sectional. }\end{array}$ & $\begin{array}{l}\text { Massachusetts, } \\
1988 .\end{array}$ & $\begin{array}{l}\text { Increasing, } \\
\text { decreasing } \\
\text { block and } \\
\text { flat rates. }\end{array}$ & $\begin{array}{l}\text { Average water } \\
\text { consumption } \\
\text { per household }\end{array}$ & $\begin{array}{l}\text { Average price of water plus sewerage, } \\
\text { average annual income per capita, population } \\
\text { density, average annual precipitation, average } \\
\text { annual temperature, billing frequency, } \\
\text { dummy variable for location of community, } \\
\text { dummies for pricing regime. }\end{array}$ & $\begin{array}{l}\text { OLS and } \\
\text { 2SLS }\end{array}$ & $\begin{array}{l}\text { Flat rate } 0.41 \text {; } \\
\text { increasing } \\
\text { block } 0.54 \text {; } \\
\text { decreasing } \\
\text { block } 0.69\end{array}$ & $\begin{array}{l}\text { Flat rate } \\
0.14 \text {; } \\
\text { increasing } \\
\text { block } 0.17 \text {; } \\
\text { decreasing } \\
\text { block } 0.28\end{array}$ & $\begin{array}{l}\text { Elasticities are not statistically } \\
\text { different between different } \\
\text { pricing structures. }\end{array}$ \\
\hline $\begin{array}{l}\text { Nieswiadomy } \\
\text { (1992) }\end{array}$ & $\begin{array}{l}\text { Cross- } \\
\text { sectional. }\end{array}$ & $\begin{array}{l}\text { United States, } \\
1984 .\end{array}$ & $\begin{array}{l}\text { Increasing, } \\
\text { decreasing } \\
\text { block and } \\
\text { flat rates. }\end{array}$ & $\begin{array}{l}\text { Average } \\
\text { monthly water } \\
\text { usage per } \\
\text { household }\end{array}$ & $\begin{array}{l}\text { Minimum charge, average price, marginal } \\
\text { price, Shin's price (perception price), income, } \\
\text { dummies for conservation and education } \\
\text { programs, regions, average monthly rainfall } \\
\text { and temperature. }\end{array}$ & OLS & n.a. & n.a. & $\begin{array}{l}\text { Conservation does not appear } \\
\text { to reduce water use. } \\
\text { Consumers react more to } \\
\text { average rather than marginal } \\
\text { prices in all regions. }\end{array}$ \\
\hline $\begin{array}{l}\text { Nieswiadomy } \\
\text { and Cobb } \\
\text { (1993) }\end{array}$ & $\begin{array}{l}\text { Cross- } \\
\text { sectional }\end{array}$ & $\begin{array}{l}\text { United States, } \\
1984 .\end{array}$ & $\begin{array}{l}\text { Increasing, } \\
\text { decreasing } \\
\text { block and } \\
\text { flat rates. }\end{array}$ & $\begin{array}{l}\text { Water use per } \\
\text { household per } \\
\text { month }\end{array}$ & $\begin{array}{l}\text { Marginal price, average price, public } \\
\text { education, number of persons per household, } \\
\text { percentage of home built before 1939, } \\
\text { percentage of homes that are owner- } \\
\text { occupied, average rainfall per month and } \\
\text { average temperature between last spring } \\
\text { freeze and first fall freeze. }\end{array}$ & $\begin{array}{l}\text { OLS and } \\
\text { Logit }\end{array}$ & $\begin{array}{l}\text { Increasing } \\
\text { block } 0.17- \\
0.64 \text {; } \\
\text { decreasing } \\
\text { block } 0.28- \\
0.46\end{array}$ & $\begin{array}{l}\text { Increasing } \\
\text { block } \\
0.57-0.63 \text {; } \\
\text { decreasing } \\
\text { block } \\
0.22-0.45\end{array}$ & $\begin{array}{l}\text { Households react to average } \\
\text { prices under both decreasing } \\
\text { and increasing block } \\
\text { structures. Increasing block } \\
\text { structures rienter } \\
\text { oriented. conservation }\end{array}$ \\
\hline $\begin{array}{l}\text { Hewitt and } \\
\text { Hanemann } \\
\text { (1995) }\end{array}$ & Panel. & $\begin{array}{l}\text { Denton, Texas } \\
\text { 1981-1985. }\end{array}$ & $\begin{array}{l}\text { Increasing } \\
\text { block rate. }\end{array}$ & $\begin{array}{l}\text { Household } \\
\text { monthly water } \\
\text { consumption }\end{array}$ & $\begin{array}{l}\text { Lawn size, weather, number of bathrooms, } \\
\text { house size, price, income (modified for } \\
\text { Nordin's difference), number of days in } \\
\text { billing period. }\end{array}$ & $\begin{array}{l}\text { OLS, IV } \\
\text { 2SLS }\end{array}$ & $1.57-1.63$ & $0.15-0.16$ & $\begin{array}{l}\text { Comparison of OLS, IV and } \\
\text { 2SLS regressions using } \\
\text { summer component. Reason } \\
\text { for high values may be } \\
\text { summer only data. }\end{array}$ \\
\hline $\begin{array}{l}\text { Barkatullah } \\
\text { (1996) }\end{array}$ & Panel. & $\begin{array}{l}\text { Sydney, New } \\
\text { South Wales, } \\
\text { 1990-1994. }\end{array}$ & $\begin{array}{l}\text { Increasing } \\
\text { block and } \\
\text { flat rates }\end{array}$ & $\begin{array}{l}\text { Quarterly } \\
\text { household water } \\
\text { consumption. }\end{array}$ & $\begin{array}{l}\text { Nordin-difference variable, marginal price, } \\
\text { average temperature, lagged rainfall, income, } \\
\text { property value, peak/off-peak dummy, } \\
\text { household size, number of bedrooms and } \\
\text { bathrooms, garden condition }\end{array}$ & $\begin{array}{l}\text { OLS, } \\
\text { 2SLSand } \\
\text { ML }\end{array}$ & 0.21 & 0.07 & $\begin{array}{l}\text { OLS provides biased and } \\
\text { inefficient estimates. } \\
\text { Consumers respond to } \\
\text { marginal prices when faced } \\
\text { with multi-part tariffs. }\end{array}$ \\
\hline
\end{tabular}




\begin{tabular}{|c|c|c|c|c|c|c|c|c|c|}
\hline Author(s) & Data & Sample & $\begin{array}{c}\text { Pricing } \\
\text { structure }\end{array}$ & $\begin{array}{l}\text { Dependent } \\
\text { variable(s) }\end{array}$ & Independent variables & $\begin{array}{l}\text { Estimation } \\
\text { technique(s) }\end{array}$ & $\begin{array}{c}\text { Price } \\
\text { elasticity }\end{array}$ & $\begin{array}{l}\text { Income } \\
\text { elasticity }\end{array}$ & Other findings \\
\hline $\begin{array}{l}\text { Dandy, } \\
\text { Nguyen and } \\
\text { Davies (1997) }\end{array}$ & Panel. & $\begin{array}{l}\text { Adelaide, } \\
\text { South } \\
\text { Australia } \\
\text { 1978- 1992. }\end{array}$ & $\begin{array}{l}\text { Increasing } \\
\text { block and } \\
\text { flat rates. }\end{array}$ & $\begin{array}{l}\text { Annual } \\
\text { household water } \\
\text { consumption }\end{array}$ & $\begin{array}{l}\text { Quantity of water consumed in the previous } \\
\text { year, annual allowance, dummy variables for } \\
\text { consumption in excess of allocation, property } \\
\text { value, household size, number of rooms, } \\
\text { climate. }\end{array}$ & OLS & $\begin{array}{l}\text { Short-run } \\
0.28 \text {; inter } \\
0.12 \text {; } \\
\text { summer } \\
0.36 \\
\text { Long-run } \\
0.77 \text {; winter } \\
0.29 \text {; } \\
\text { summer } \\
0.86\end{array}$ & $\begin{array}{l}\text { Short-run } \\
0.14 ; \\
\text { winter } \\
0.16 \text {; } \\
\text { summer } \\
0.15 \\
\text { Long-run } \\
0.38 ; \\
\text { winter } \\
0.33 \text {; } \\
\text { summer } \\
0.49\end{array}$ & $\begin{array}{l}\text { Free water allowance results in } \\
\text { wastage and that its removal } \\
\text { would be an efficient way of } \\
\text { reducing water consumption. } \\
\text { Little equity impact through } \\
\text { removal of allowance }\end{array}$ \\
\hline $\begin{array}{l}\text { Renwick, } \\
\text { Green and } \\
\text { McCorkle } \\
\text { (1998) }\end{array}$ & Panel. & $\begin{array}{l}\text { California, } \\
\text { 1989-1996. }\end{array}$ & $\begin{array}{l}\text { Increasing } \\
\text { block and } \\
\text { flat rates. }\end{array}$ & $\begin{array}{l}\text { Average } \\
\text { monthly } \\
\text { household water } \\
\text { use }\end{array}$ & $\begin{array}{l}\text { Alternative non-price demand management } \\
\text { policies, marginal price, difference term, } \\
\text { income, lot size, precipitation (difference } \\
\text { from mean), persons per household; }\end{array}$ & 2SLS & $0.16-0.20$ & n.a. & $\begin{array}{l}\text { Failure to account for the } \\
\text { influence of non-price demand } \\
\text { side management policies may } \\
\text { result in an overestimate of the } \\
\text { price responsiveness of water } \\
\text { demand. }\end{array}$ \\
\hline $\begin{array}{l}\text { Renwick and } \\
\text { Archibald } \\
\text { (1998) }\end{array}$ & Panel. & $\begin{array}{l}\text { California, } \\
\text { 1986-1990. }\end{array}$ & $\begin{array}{l}\text { Increasing } \\
\text { block rate. }\end{array}$ & $\begin{array}{l}\text { Total water } \\
\text { consumption }\end{array}$ & $\begin{array}{l}\text { Marginal price of water, Nordin difference, } \\
\text { policy dummies for restriction, allocation and } \\
\text { rebates on water saving technology, adoption } \\
\text { of water saving technologies, gross monthly } \\
\text { household income, number of household } \\
\text { members, housing density, number of } \\
\text { faucets, inflation, cumulative monthly } \\
\text { rainfall. }\end{array}$ & $\begin{array}{l}\text { 2SLSand } \\
\text { OLS }\end{array}$ & $\begin{array}{l}\text { Overall } \\
0.33 ; \text { low } \\
\text { income } \\
0.53 ; \\
\text { middle } \\
\text { income } \\
0.21 \text {; high } \\
\text { income } 0.11\end{array}$ & 0.36 & $\begin{array}{l}\text { Higher water prices are } \\
\text { expected to directly reduce } \\
\text { demand in the short run and } \\
\text { stimulate the demand for water } \\
\text { efficient technologies by } \\
\text { increasing the relative benefits } \\
\text { associated with adoption in the } \\
\text { medium to long run. }\end{array}$ \\
\hline Pint (1999) & Panel. & $\begin{array}{l}\text { Alameda, } \\
\text { Spain, } \\
1982-1992 .\end{array}$ & $\begin{array}{l}\text { Increasing } \\
\text { block and } \\
\text { flat rates. }\end{array}$ & $\begin{array}{l}\text { Household } \\
\text { water use as a } \\
\text { deviation from } \\
\text { average use }\end{array}$ & $\begin{array}{l}\text { House size, lot size, precipitation, lagged } \\
\text { precipitation, temperature and lagged } \\
\text { temperature, marginal price and price } \\
\text { squared. }\end{array}$ & $\begin{array}{l}\text { OLS and } \\
\text { ML }\end{array}$ & $\begin{array}{l}\text { Summer } \\
0.20-0.47 \text {; } \\
\text { winter } 0.33- \\
1.24\end{array}$ & n.a. & $\begin{array}{l}\text { Maximum likelihood models } \\
\text { that explicitly consider the } \\
\text { household's response to the } \\
\text { rate structure result in } \\
\text { plausible estimates of water } \\
\text { demand. }\end{array}$ \\
\hline $\begin{array}{l}\text { Hoglund } \\
\text { (1999) }\end{array}$ & Panel. & $\begin{array}{l}\text { Sweden, } \\
1980-1992 .\end{array}$ & $\begin{array}{l}\text { Flat rates } \\
\text { and } \\
\text { decreasing } \\
\text { block rates. }\end{array}$ & $\begin{array}{l}\text { Average } \\
\text { household } \\
\text { consumption } \\
\text { per person per } \\
\text { day. }\end{array}$ & $\begin{array}{l}\text { Marginal price of water, fixed price for } \\
\text { typical household, average price, gross } \\
\text { household income, average household size, } \\
\text { regional dummy variables. }\end{array}$ & $\begin{array}{l}\text { OLS, GLS } \\
\text { and 2SLS }\end{array}$ & $\begin{array}{l}\text { Marginal } \\
0.08-0.12 ; \\
\text { average } \\
0.20-0.26 \text {; } \\
\text { fixed } 0.01- \\
0.02 \text {. }\end{array}$ & $0.07-0.13$ & $\begin{array}{l}\text { Strong regional variation in } \\
\text { household consumption, } \\
\text { significant scale economies in } \\
\text { household water consumption. }\end{array}$ \\
\hline
\end{tabular}




\begin{tabular}{|c|c|c|c|c|c|c|c|c|c|}
\hline Author(s) & Data & Sample & $\begin{array}{l}\text { Pricing } \\
\text { structure }\end{array}$ & $\begin{array}{l}\text { Dependent } \\
\text { variable(s) }\end{array}$ & Independent variables & $\begin{array}{c}\text { Estimation } \\
\text { technique(s) }\end{array}$ & $\begin{array}{c}\text { Price } \\
\text { elasticity }\end{array}$ & $\begin{array}{c}\text { Income } \\
\text { elasticity }\end{array}$ & Other findings \\
\hline $\begin{array}{l}\text { Rietveld, } \\
\text { Rouwendal } \\
\text { and Zwart } \\
(2000)\end{array}$ & $\begin{array}{l}\text { Cross } \\
\text { sectional. }\end{array}$ & $\begin{array}{l}\text { Salatiga, } \\
\text { Indonesia } \\
1994 .\end{array}$ & $\begin{array}{l}\text { Increasing } \\
\text { block rate. }\end{array}$ & $\begin{array}{l}\text { Monthly water } \\
\text { consumption. }\end{array}$ & $\begin{array}{l}\text { Marginal price of water, "virtual income" to } \\
\text { account for lower infra-marginal price paid } \\
\text { for the first allocation of water, household } \\
\text { size, and availability of non-piped water. }\end{array}$ & OLS & $1.28-1.16$ & n.a. & $\begin{array}{l}\text { Demand depends on household } \\
\text { size and presence of } \\
\text { alternative supply. }\end{array}$ \\
\hline $\begin{array}{l}\text { Gaudin, } \\
\text { Griffin and } \\
\text { Sickles } \\
\text { (2001) }\end{array}$ & Panel. & $\begin{array}{l}\text { Texas, } \\
1981-1985 .\end{array}$ & $\begin{array}{l}\text { Increasing } \\
\text { block rate. }\end{array}$ & $\begin{array}{l}\text { Water } \\
\text { consumption } \\
\text { per capita per } \\
\text { month }\end{array}$ & $\begin{array}{l}\text { Average price, per capita income, proportion } \\
\text { of population of Spanish origin, climate, } \\
\text { average annual precipitation }\end{array}$ & $\begin{array}{l}\text { OLS and } \\
\text { GLS }\end{array}$ & $\begin{array}{l}\text { Overall } \\
0.19-0.47 \\
\text { Summer } \\
0.12-0.15 \\
\text { winter } \\
0.24 \text { to } 0.27\end{array}$ & $0.11-0.19$ & $\begin{array}{l}\text { Results suggest that } \\
\text { approximately } 3 / 4 \text { of total water } \\
\text { usage is not responsive to price } \\
\text { changes }\end{array}$ \\
\hline $\begin{array}{l}\text { Higgs and } \\
\text { Worthington } \\
\text { (2001) }\end{array}$ & Panel. & $\begin{array}{l}\text { Brisbane, } \\
\text { Queensland, } \\
1996 .\end{array}$ & $\begin{array}{l}\text { Fixed } \\
\text { charge } \\
\text { unlimited } \\
\text { allowance } \\
\text { with } \\
\text { simulation } \\
\text { of two-part } \\
\text { tariff with } \\
\text { zero fixed } \\
\text { allowance } \\
\text { and flat rate. }\end{array}$ & $\begin{array}{l}\text { Household } \\
\text { quarterly water } \\
\text { consumption. }\end{array}$ & $\begin{array}{l}\text { Household income, value of property, } \\
\text { marginal price under the user-pays system, } \\
\text { seasonal dummy, number of household } \\
\text { members, other house characteristics, and } \\
\text { soil characteristic. }\end{array}$ & IV and Logit & n.a. & n.a. & $\begin{array}{l}\text { Because of uncertainty } \\
\text { associated with future } \\
\text { household water demand, the } \\
\text { option to remain on the non- } \\
\text { user pays system has value and } \\
\text { is incorporated into the } \\
\text { appropriate decision-making } \\
\text { model. }\end{array}$ \\
\hline $\begin{array}{l}\text { Martinez- } \\
\text { Espineira } \\
\text { (2002) }\end{array}$ & Panel. & $\begin{array}{l}\text { Spain, } \\
\text { 1993-1999. }\end{array}$ & $\begin{array}{l}\text { Two-part } \\
\text { tariff with } \\
\text { fixed } \\
\text { allowance } \\
\text { and } \\
\text { increasing } \\
\text { block and } \\
\text { flat rates. }\end{array}$ & $\begin{array}{l}\text { Average } \\
\text { monthly } \\
\text { consumption. }\end{array}$ & $\begin{array}{l}\text { Average temperature, population density, } \\
\text { household size, fixed component of water } \\
\text { and sewerage bill, billing period, income } \\
\text { index, marginal price, population over } 64 \\
\text { years and under } 19 \text { year, precipitation, } \\
\text { percentage of housing as main residence } \\
\text { dwelling, tourism index, Nordin-difference. }\end{array}$ & IV & $0.12-0.17$ & n.a. & $\begin{array}{l}\text { Significant difference in } \\
\text { summer-only elasticities and } \\
\text { major impact of climatic } \\
\text { variables on } \text { monthly } \\
\text { consumption. }\end{array}$ \\
\hline $\begin{array}{l}\text { Timmins } \\
\text { (2002) }\end{array}$ & Panel. & $\begin{array}{l}13 \text { cities, San } \\
\text { Joaquin } \\
\text { Valley, } \\
\text { California, } \\
\text { 1970-1993. }\end{array}$ & $\begin{array}{l}\text { Increasing, } \\
\text { decreasing } \\
\text { block and } \\
\text { flat rates. }\end{array}$ & $\begin{array}{l}\text { Quantity } \\
\text { demanded }\end{array}$ & $\begin{array}{l}\text { Typical rate structure consists of three } \\
\text { components: (i) a service charge (ii) some } \\
\text { quantity of water and (iii) marginal rate } \\
\text { charge for each additional acre foot of water } \\
\text { consumed, annual rainfall, number of active } \\
\text { residential service connections; dummy for } \\
\text { cities. }\end{array}$ & OLS & n.a. & n.a. & $\begin{array}{lr}\text { Municipal } & \text { water } \\
\text { administrators charge below } \\
\text { marginal cost and in so doing } \\
\text { inefficiently exploit aquifer } \\
\text { stocks and induce social } \\
\text { surplus losses. }\end{array}$ \\
\hline
\end{tabular}




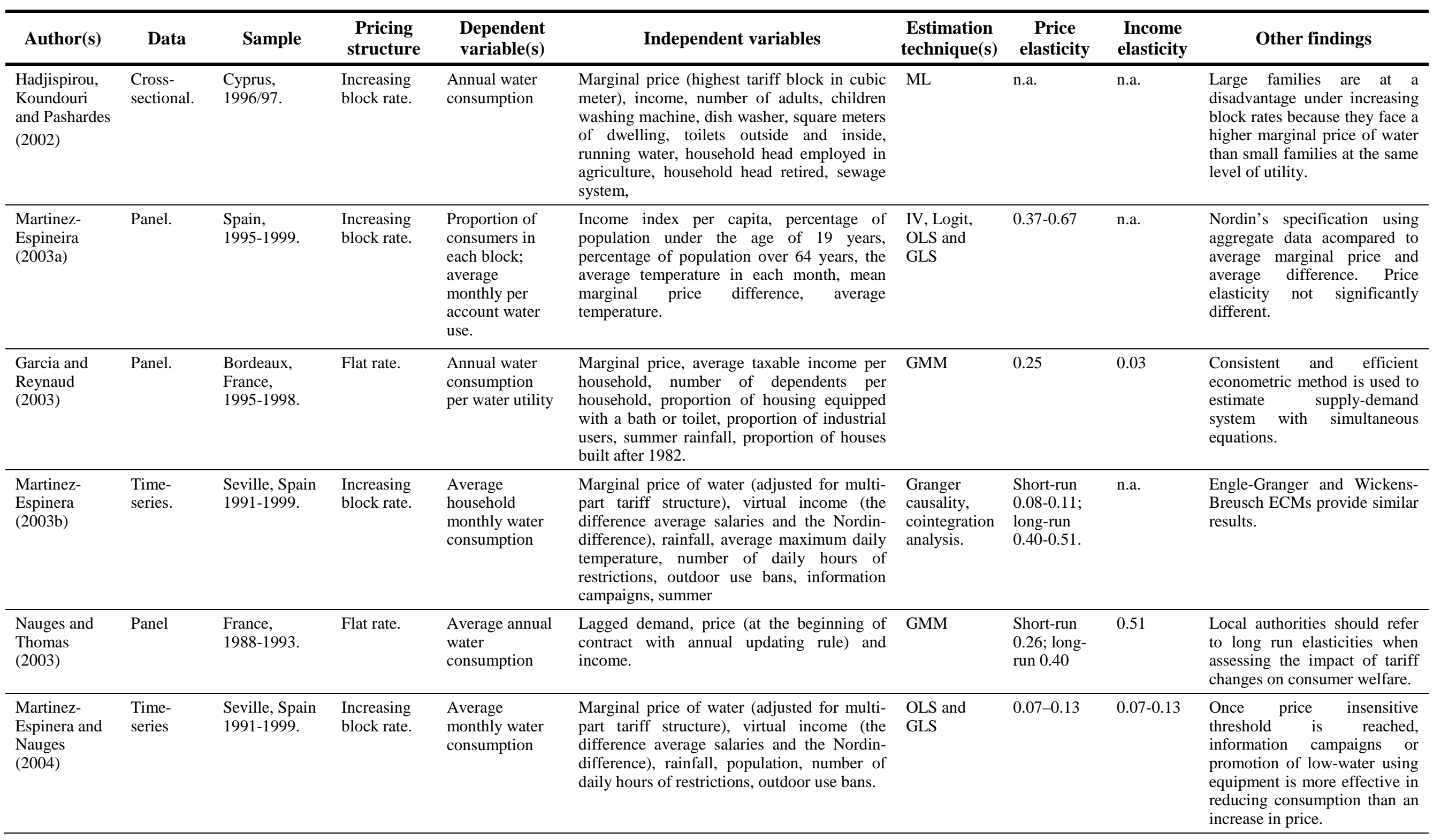




\begin{tabular}{|c|c|c|c|c|c|c|c|c|c|}
\hline Author(s) & Data & Sample & $\begin{array}{l}\text { Pricing } \\
\text { structure }\end{array}$ & $\begin{array}{l}\text { Dependent } \\
\text { variable(s) }\end{array}$ & Independent variables & $\begin{array}{l}\text { Estimation } \\
\text { technique(s) }\end{array}$ & $\begin{array}{c}\text { Price } \\
\text { elasticity }\end{array}$ & $\begin{array}{l}\text { Income } \\
\text { elasticity }\end{array}$ & Other findings \\
\hline $\begin{array}{l}\text { Hoffman, } \\
\text { Worthington } \\
\text { and Higgs } \\
(2006)\end{array}$ & Panel & $\begin{array}{l}\text { Brisbane, } \\
\text { Queensland, } \\
\text { 1998-2003. }\end{array}$ & $\begin{array}{l}\text { Two-part } \\
\text { tariff with } \\
\text { zero } \\
\text { allowance } \\
\text { and flat rate. }\end{array}$ & $\begin{array}{l}\text { Quarterly } \\
\text { annual water } \\
\text { consumption }\end{array}$ & $\begin{array}{l}\text { Marginal price of water, household income } \\
\text { and size, number of rainy and warm days in } \\
\text { quarter, summer dummy. }\end{array}$ & OLS & $\begin{array}{l}\text { Short-run } \\
0.51 \text {; long- } \\
\text { run } 1.16\end{array}$ & 0.23 & $\begin{array}{l}\text { Price and income elasticity } \\
\text { higher in owner-occupied } \\
\text { households than renter } \\
\text { households. Summer and rainy } \\
\text { days exert strong influence on } \\
\text { residential water consumption. }\end{array}$ \\
\hline $\begin{array}{l}\text { Gaudin } \\
\text { (2006) }\end{array}$ & $\begin{array}{l}\text { Cross- } \\
\text { section }\end{array}$ & $\begin{array}{l}\text { United States, } \\
1995 .\end{array}$ & $\begin{array}{l}\text { Uniform, } \\
\text { decreasing } \\
\text { and } \\
\text { increasing } \\
\text { block rates. }\end{array}$ & $\begin{array}{l}\text { Per capita } \\
\text { residential } \\
\text { consumption }\end{array}$ & $\begin{array}{l}\text { Average price of water, per capita income, } \\
\text { average number of household members, } \\
\text { population density, average annual } \\
\text { precipitation, number of high temperature } \\
\text { days. }\end{array}$ & OLS, 2SLS & 0.37 & 0.30 & $\begin{array}{l}\text { Price information on water } \\
\text { bills has a significant positive } \\
\text { influence on elasticity. }\end{array}$ \\
\hline
\end{tabular}

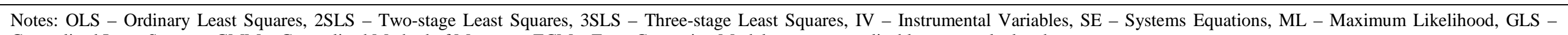
Generalised Least Sqaures, GMM - Generalised Method of Moments, ECM - Error Correction Model, n.a - not applicable or not calculated. 